\title{
Educational Paradigm Shift: Are We Ready to Adopt MOOC?
}

http://dx.doi.org/10.3991/ijet.v9i4.3756

\author{
Jayakumar Sadhasivam \\ VIT University, Vellore, India
}

\begin{abstract}
This survey paper encapsulates the findings from an empirical study carried out on online learning. The impact of information technology in our day-to-day life has been profound. Because of this many cross disciplines that have been enriched (or benefited) by information technology, and the educational media is a major one among them. On the context of eLearning, Massive Open Online Courses (MOOC) [20] had contributed a larger portion to deliver an integration of learning, teaching and assessment. MOOC is a Web-based tool for distance-learning environment, designed for the participation of large numbers of geographically dispersed audience [11]. In addition, Google and other companies are involved in the design and funding towards a low-cost eLearning. Niche market provides certification courses via MOOC, to satisfy the employee's specific needs [12]. However, in the present day context the opinion on embracing MOOC by any University has been quite debatable. Addressing this debate on both sides, this paper presents the opinion expressed by the stakeholders in education towards embracing MOOC. The survey is focused on providing a consolidated fact that is based on penetration of eLearning. A survey was carried out to provide a solid analysis of eLearning with the help of IT infrastructure in India. On the analysis of the survey from faculty, students and system administrator it revealed demographic distribution of 39.6 percentages from the overall participant of 792 out of 2000 . Based on the findings from the study, the paper also discusses the challenge and broad concerns applicable to eLearning in India.
\end{abstract}

Index Terms-MOOC, Education, Online Education, Distance Education, eLearning

\section{INTRODUCTION}

The present paper delineates the effect of digital divide in distance education. Access to technology is defined by what students do not know about it. It is called digital divide. Access is based on the speed of the Internet connections. Access in future may be greater as more computers emerge. Using qualitative research method, document materials, data collection, carried out the study. The result was distance education played a key role, gave hope and enthusiasm to the learners despite of the government lack in infrastructures, electricity, postal and telecommunication services. The study mainly deals with the survey of different classifications of online distance education and the methods handled or used by the faculties, administrators, universities and colleges to educate students.

Distance education uses various combinations of print and non- print learning materials. Tutorials and group discussion also support learning. Technology gives expanded and independent learning opportunities. There are still a number of deprived urban neighbourhoods with unskilled workers, poorly educated youth, and limited resources. The main cause of digital divide is the lack of access to information and training of high-tech jobs. Technology has given root to fulfil the needs of the people. Thus education has become a lifelong process.

Online courses are delivered by using Learning Management System but we are moving towards resourcebased course packages, instead of a main textbook or modules authored by one writer or team of writers, instructors are looking for various resources to help them achieve their course goals. They are using Web-based publications and other materials in digital format such as podcasts, webcasts. The features of Web 2.0 such as blogs, wikis, shareware and virtual communities are popular in the recent scenario. The potential of mobile technology in the course delivery process has become the trend. This is important when teaching adults. Active learning meets the expectations of the students and makes an effective learning experience.

By teaching how to use the World Wide Web properly and search the various databases for articles, the teacher led the students towards better and more useful material needed in their studies. Library professionals, particularly in the academia, realize that information literacy plays a critical role in learning process. The goal is to help students succeed, not only in college but also in their lifelong carrier choices.

Recent advancement in the IT services becomes the intensity to provide the greater online education. Education has seen many changes over many years. From classroom education the focus has changed towards eLearning significantly in the last few years. Despite the prominence of classroom education, Students and Teachers need to meet the regular scheduled times on the same day each week. Learner and educator need to meet in scheduled times. Teachers turn into a basic-skills tutor. No differences in extra/tutor classes. Time to teach the strategies must be taken from academic work. General education teacher may not follow up on strategy usage. Implementation usually requires attendance in a strategy workshop by the learning disabilities teacher [13], there exists several disadvantages associated with classroom education. In an effort to overcome the drawbacks of classroom education, technologists and tutors have turned their attention to eLearning. IT infrastructure has made an impact on the $21^{\text {st }}$ century generation. The evidence is viable with increasing number of sales in smartphones, tablets, PC and laptops. Supporting IT service has also seen an experimental growth. Example YouTube, vimeo, MySpace etc. As a consequence, educators turn to IT platform for reducing out to under audience. As we have seen the impact of 
growth in learning methodologies. With the recent technological innovation for education is MOOCs, Massive Open Online Courses Started in 2008; the year 2012 was declared as the Year of MOOCs Free courses available online Large enrolment Learning through self exploration and cooperation of peers. Online Learning $32 \%$ of students in US take at least one course online (2013) Only about 100,000 online learners in Commonwealth Asia Online learning in India is less than 15 year old. MOOCs the non-profit start-up from Harvard and the Massachusetts Institute of Technology, has 370,000 students this fall in its first official courses. Coursera, founded just last January, has reached more than 1.7 million - growing "faster than Facebook"[14], Google released a MOOCbuilding online tool[15]. However, in the present day context the opinion on embracing MOOC by an University has been quite debatable. In the Indian context, many universities are embracing IT infrastructure and services for the administration and management purposes. Nevertheless, the use of technology for teaching large-scale number of students has been on the downside comparatively. Addressing this issue, the paper outlines some of the opinions expressed by the stakeholders of education. The result has been summarized.

\section{Literature REVIEW}

During the early part of 80's Indian Government initiated a scheme on Computer Literature And Social on School (CLASS) across 2598 schools marking the first step towards eLearning in India. Following the success of the previous scheme, in the year 2003, the project was extended with the intention of having a school in each and every district of India. As a result of the scheme more than 600,000 schools were established.

The first online education enterprise Netvarsity was introduced in National Institute of Information Technology (NIIT) [16] with private initiative in 1996, although In 1991, Indira Gandhi National Open University (IGNOU)[22] started telecasting their educational programmes on Doordarshan. In 1999, a virtual campus initiative was started by IGNOU with programs such as the Bachelor of Information Technology (BIT) and Advance Diploma in Information Technology (ADIT) (in collaboration with Edexel, UK, and India). In joint collaboration of Govt of India, PrasarBharti and IGNOU, Gyandaeshan education channel was started in 2000 to telecast educational program round the clock. Indian institute of management Bangalore (IIM-B) used e-Learning face-to-face teaching method. UGC organized a dialogue on "Enhancing Higher Education Through E-learning" in collaboration with Commonwealth of Learning (COL) vancover from M-19 November 2003 at Delhi. World's first educational satellite was launched by ISRO in $20^{\text {th }}$ September 2004 named EDUSAT [17] to provide education to millions of people at their doorstep to enable information to be broadcasted in local language and has devoted to long distance learning in India.

\section{Present Status of eLearning}

At present, many universities across the world have initiated to offer many courses ranging from undergraduate to $\mathrm{PhD}$ with the help of eLearning platform. According to the latest survey conducted by the Common wealth of Learning, there are nearly 4.2 million learners are learning through e-learning and Open Distance Education in India.
The technical courses those which are offered under the eLearning umbrella are currently being governed by All India Council for Technical Education (AICTE) and University Grants Commission (UGC) along with the assistance ofDistance Education Council (DEC) Committee.

Among the students who have participated in these courses, $27 \%$ are women and people with various disabilities. The survey report also concludes that the average cost of graduate through distance education is reduced by $65 \%$ compared to traditional classroom education, offered mostly in universities.

Since 2009 , India shows an increase of $50 \%$ in total elearning enterprises, having more than 200 e-learning enterprises. Indian e-learning industry is vast which employs 18-20,000 people with annual revenue of US \$550600 Million[23]. The industry regenerates to grow at 18 $20 \%$ CAGR every year. Indian domestic e-learning market is estimated to be around $\$ 50-55$ Million (About Rs.200-250 Cr) on the domestic front or about $10 \%$ of the total industry size[24].

\section{ANALYSIS}

\section{A. Assessment of Faculties and Student Categories by Age and Gender}

The assessment of faculties and student categories by gender and age is as follows.

TABLE I.

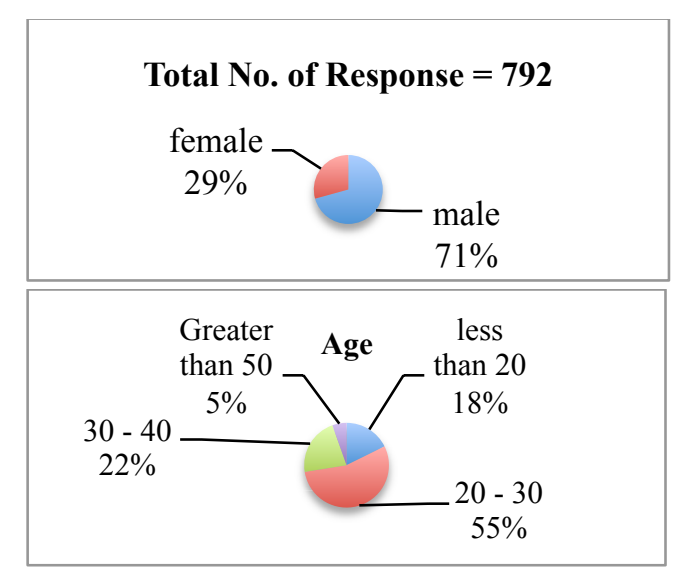

In table I, we can classify the number of respondents in the university. According to it, we classify the above assessment into two different categories; one details the distribution of members and the other on gender classification. Here, $18 \%$ of respondent's is less than the age of 20. Likewise, all of them are classified into four categories. In this table 1.1, all faculty members, students and research scholars are included.

\section{B. Distribution of Online Distance Education-Course Wise and Session Wise in Each Semester}

In this distribution, we came to know about Online Distance Education for course wise as well as session wise in each semester.

The Table II shows the number of courses, Percentage of respondents studying the course and also the session wise classification. In session wise, we can confirm the timings or the sessions and the number of members needs 
to be attended, and this classification tells us the number of courses and the sessions for the courses for every fresh semester. Here we also come to know the percentage of attendees in session wise. In order to complete a single course, attending one or two sessions is more than enough. Session will be allocated based on the course alone. The percentage in registration defines the maximum number of courses in percentage wise. The range is high only for a minimum number of sessions. It is proved that the students are neither concentrating nor focusing on the number of sessions. $5+$ courses will take more than 10 sessions to complete. It looks difficult for the students to complete that many courses. Hence the percentage for taking such type of sessions is also comparatively limited. Here it is $30 \%$ for our total number of students. Course wise overall total is $60 \%$, the overall percentage of students who have taken this course is only $49 \%$. Finally the above survey tells that maximum number of students taking the course is less than the course offered.

\section{Estimation of Content type used both in Online and Traditional Courses}

The estimation talks about the materials and software developed by college for Online and Traditional courses. In the table II, the estimation defines about the different electronic content purpose and hardcopy content and software developed by different instructors for traditional class and online education development. Here each and every topic generalized into different sub categories.

The Table II explains that eLearning and Traditional Class should have their percentage allocation for each and every course. Faculty members develop the digitalized materials. These types of materials are used up to $90 \%$ in eLearning. Here the advantage is to reduce the task of humans, but the traditional class is using less than $10 \%$. Hence the students cannot go further with other subjects. The major disadvantage between eLearning and Traditional method is that in traditional, the students or faculty can have only limited or allocated duration to complete the work where as in eLearning, soon after the student completes the work, they can go ahead with other topics, here the time allocation is based on the student's understanding of the subject. The above survey shows that eLearning has a better place and has an edge for both faculty members and students.

\section{Implementation of Effective Distance Education at College/ University}

Discussing various classification levels of Distance Education based on barrier.

In the Table IV, we classified the technological and administrative levels of the colleges/ universities so that, we know the implementation levels of the effective distance education. The effectiveness or the judgment of the college/ Universities is based on different levels and the new innovation in education. Here the barrier talks about the classification in the calculation of total number of members. The table IV includes infrastructure, faculty, administration, student barriers, Faculty compensation, copyright issues, restrictions and workloads. Each and every category in the table is taken for total number of members. For each and every category, there will be five classifications from rating 1 to 5 . So, we came to know, which category is having the highest and lowest weightage based on percentage. Some of them will take equal
TABLE II.

\begin{tabular}{|c|c|c|c|}
\hline Course Wise & $\begin{array}{c}\text { Percentage in } \\
\text { Registration }\end{array}$ & Session Wise & $\begin{array}{c}\text { Percentage in } \\
\text { Attendees }\end{array}$ \\
\hline 1 Course & $80 \%$ & 1 to 2 Sessions & $60 \%$ \\
\hline 2 Course & $75 \%$ & 2 to 4 Sessions & $50 \%$ \\
\hline 3 Courses & $60 \%$ & 3 to 5 Sessions & $55 \%$ \\
\hline 4 Courses & $45 \%$ & 5 to 8 Sessions & $50 \%$ \\
\hline $5+$ Courses & $40 \%$ & 10 + Sessions & $30 \%$ \\
\hline Overall $\%$ & $60 \%$ & Overall $\%$ & $49 \%$ \\
\hline
\end{tabular}

TABLE III.

\begin{tabular}{|l|l|l|}
\hline Description & $\begin{array}{l}\text { eLearn- } \\
\text { ing }\end{array}$ & $\begin{array}{l}\text { Traditional } \\
\text { Class }\end{array}$ \\
\hline Digital materials developed by concerned faculty & $60-90 \%$ & Less than $10 \%$ \\
\hline $\begin{array}{l}\text { Digital materials developed by co-worker (your } \\
\text { college) }\end{array}$ & $60-90 \%$ & $10-40 \%$ \\
\hline Digital materials developed by another instructor & $90-100 \%$ & Less than $10 \%$ \\
\hline $\begin{array}{l}\text { Electronic content purchased from external } \\
\text { vendor }\end{array}$ & $20-45 \%$ & $60-90 \%$ \\
\hline Free electronic content (Open web resources) & $73-90 \%$ & None \\
\hline Test management software (Moodle \& LMS) & $15-40 \%$ & None \\
\hline
\end{tabular}

TABLE IV.

TOTAL NO. OF PARTICIPANTS N=792 - ACCORDING TO VARIOUS BARRIERS IN \%

\begin{tabular}{|l|l|l|l|l|l|}
\hline Description & $\mathbf{1}$ & $\mathbf{2}$ & $\mathbf{3}$ & $\mathbf{4}$ & $\mathbf{5}$ \\
\hline $\begin{array}{l}\text { Inadequate technology } \\
\text { infrastructure }\end{array}$ & 16.79 & 6.19 & 50.25 & 10.23 & 6.35 \\
\hline Reluctant faculties & 23.61 & 12.37 & 19.70 & 31.31 & 2.49 \\
\hline Managerial reluctance & 8.59 & 21.84 & 11.36 & 33.21 & 1.43 \\
\hline Student barrier & 9.60 & 14.02 & 29.29 & 26.77 & 3.70 \\
\hline $\begin{array}{l}\text { Inadequate faculty } \\
\text { compensation }\end{array}$ & 41.79 & 39.02 & 12.37 & 5.30 & 1.56 \\
\hline $\begin{array}{l}\text { Unresolved copy- } \\
\text { right/intellectual property } \\
\text { issues }\end{array}$ & 6.82 & 9.97 & 22.22 & 47.22 & 2.81 \\
\hline Class size restrictions & 29.04 & 50.38 & 12.37 & 8.21 & 1.56 \\
\hline Greater Workload & 5.68 & 14.52 & 5.68 & 46.84 & 0.72 \\
\hline
\end{tabular}

percentage and some others will have difference with each other. Here we can clearly understand that the workload is reduced in distance education. Here we don't have any specific restrictions for amount of students for each course. We have it very high or no percentage also. It depends upon the mentality of the students based on the course. The faculty allocation and the student's allocations are different in distance education.

\section{E. Frequency of Online Services}

Online Services are describing the utilization of information via web or by utilizing the software accessibility by collaborating with Academic Computing and/or Disabled Student Services to check their accessibility. But some students can check their Academic performance alone by using intranet facility. Table $\mathrm{V}$ shows the usage and frequency of the Online Services.

Table V explains various web and software facilities that we can use in colleges/Universities. There are different classifications of education that we are handling in a college/Universities. Every classification is divided into 
five sub parts based on its usage. The mentality of the students and faculty members cannot be justified. Changes are made at the time of unavoidable situation. The Table $\mathrm{V}$ explains the usage of classifications with total number of members.

It shows the weightage of each and every classification. The students and faculty members always use their college website for getting the daily updates. According to the survey, we are still lacking in video conferencing, financial aid and Webmaster. Video conferencing is one of the best tools for online education. Web master is quite similar to video conferencing, but here we can't interact with each other, only we can listen. Online services always play a vital role in distance education.

\section{F. Challenges for Faculty and Administrators in Distance Education Classes}

There are some challenges for faculty members and administrators in distance education classes. There are some challenges such as handling of workload and training the students and administrative problems including student evaluation and preparation for classes.

Table VI explains the challenges faced by the faculty. When we consider the workload, it differs from department to department and subject to subject.

Table VII explains the challenges faced by the administrators. It is clear that they face issues such as handling computer effectively and providing technical support to client and network, and also providing virtual services to students.

\section{G. Barrier to Student Success in Online Distance Education Classes}

In this survey, the drawbacks and barriers for the student to get success in online Distance Education have been displayed. The different classifications explain us the concept to get success. Here we are targeting the lack of student activities in online education and the problems they are facing in their day-to-day schedules. This student's activity involves all the key factors that help complete the online education tasks. Table VIII explains the barriers that students in online distance education.

Survey tells that the students are lacking in online services, self-motivation and self-education, managing time and interacting with people face-to-face. There are some other issues faced by students such as language skills and technical support. The technical problem is due to server error, slow network connection, etc. The students are not able to do the task assigned to them due to the technical network problems.

\section{H. General Evaluation of Online Distance Education}

In Table IX, the overall performance and usage of online education is evaluated. The performance and course objectives in the survey are very clear, because it is pre planned or previously maintained work. The course procedure is different while comparing to the objective because it will get differed while the student is performing on the particular task.

At that time, it becomes dissatisfied. When compared to traditional, online learning has better resource repositories for learning.
TABLE V

RATING 1 TO 5 - ACCORDING TO THE PERCENTAGE OF USERS USAGE (\%) $\mathrm{N}=792$

\begin{tabular}{|l|l|l|l|l|l|}
\hline Description & $\mathbf{1}$ & $\mathbf{2}$ & $\mathbf{3}$ & $\mathbf{4}$ & $\mathbf{5}$ \\
\hline Library & 1.26 & 4.29 & 10.73 & 20.96 & 62.75 \\
\hline Video Conferencing & 82.58 & 1.77 & 6.06 & 1.14 & 8.46 \\
\hline Financial aid & 16.79 & 3.03 & 9.97 & 44.95 & 25.25 \\
\hline E-college tech support & 1.52 & 6.19 & 14.14 & 30.56 & 47.60 \\
\hline Admissions \& records & 0.25 & 1.64 & 11.36 & 16.54 & 70.20 \\
\hline Online bookstore & 4.04 & 5.68 & 33.71 & 15.28 & 41.29 \\
\hline Google books & 2.15 & 18.31 & 20.45 & 2.53 & 56.57 \\
\hline Your college website & 0.88 & 2.02 & 3.03 & 6.94 & 87.12 \\
\hline E-college student tutorial & 3.28 & 4.04 & 10.61 & 27.53 & 54.55 \\
\hline Online distance education & 9.85 & 4.04 & 30.56 & 20.33 & 35.23 \\
\hline Orientation & 19.19 & 10.73 & 27.15 & 23.86 & 19.07 \\
\hline Webmaster & 19.07 & 6.94 & 40.66 & 22.22 & 11.11 \\
\hline
\end{tabular}

TABLE VI.

RATING 1 TO 5 - ACCORDING TO THE PERCENTAGE OF USERS USAGE (\%) $\mathrm{N}=792$

\begin{tabular}{|l|l|l|l|l|l|}
\hline Description & $\mathbf{1}$ & $\mathbf{2}$ & $\mathbf{3}$ & $\mathbf{4}$ & $\mathbf{5}$ \\
\hline Workload & 3.16 & 8.21 & 16.54 & 40.53 & 31.57 \\
\hline Training & 25.00 & 33.21 & 11.36 & 21.84 & 8.59 \\
\hline Compensation & 6.06 & 1.77 & 82.58 & 1.14 & 8.46 \\
\hline Electronically delivered instruction & 6.06 & 5.93 & 13.26 & 33.71 & 41.04 \\
\hline Technical support & 17.93 & 11.36 & 23.11 & 16.67 & 30.93 \\
\hline Recruitment & 12.63 & 15.15 & 27.15 & 28.41 & 16.67 \\
\hline Intellectual property/ownership issues & 1.26 & 4.29 & 23.36 & 20.96 & 50.13 \\
\hline
\end{tabular}

TABLE VII.

RATING 1 TO 5 - ACCORDING TO THE PERCENTAGE OF USERS USAGE (\%) $\mathrm{N}=792$

\begin{tabular}{|l|l|l|l|l|l|}
\hline Description & 1 & 2 & 3 & 4 & 5 \\
\hline Completion of student evaluations & 3.28 & 41.92 & 23.23 & 4.04 & 27.53 \\
\hline $\begin{array}{l}\text { Orientation / preparation for taking } \\
\text { distance education classes }\end{array}$ & 9.85 & 29.29 & 5.30 & 35.23 & 20.33 \\
\hline $\begin{array}{l}\text { Assessing the student learning and } \\
\text { performance in distance educational } \\
\text { classes }\end{array}$ & 1.14 & 22.22 & 47.22 & 22.60 & 6.82 \\
\hline $\begin{array}{l}\text { Computer problems and providing the } \\
\text { technical support }\end{array}$ & 0.63 & 7.58 & 12.37 & 50.38 & 29.04 \\
\hline $\begin{array}{l}\text { Providing equivalent student services } \\
\text { virtually }\end{array}$ & 15.15 & 6.06 & 4.04 & 41.04 & 33.71 \\
\hline $\begin{array}{l}\text { Recruitment / interest in distance } \\
\text { education by students }\end{array}$ & 17.93 & 11.36 & 23.11 & 16.67 & 30.93 \\
\hline
\end{tabular}

TABLE VIII.

RATING 1 TO 5 - ACCORDING TO THE PERCENTAGE OF USERS USAGE (\%) $\mathrm{N}=792$

\begin{tabular}{|l|l|l|l|l|l|}
\hline Description & $\mathbf{1}$ & $\mathbf{2}$ & $\mathbf{3}$ & $\mathbf{4}$ & $\mathbf{5}$ \\
\hline Inadequate technology skills & 3.28 & 16.67 & 10.61 & 27.53 & 41.92 \\
\hline $\begin{array}{l}\text { Insufficient technical } \\
\text { support }\end{array}$ & 9.85 & 16.67 & 17.93 & 7.70 & 47.85 \\
\hline Insufficient language skills & 19.19 & 23.36 & 14.52 & 23.86 & 19.07 \\
\hline Class size too large & 25.00 & 8.59 & 11.36 & 21.84 & 33.21 \\
\hline $\begin{array}{l}\text { Inaccessibility for students } \\
\text { with disabilities }\end{array}$ & 9.60 & 26.77 & 14.02 & 29.29 & 20.33 \\
\hline $\begin{array}{l}\text { Lack of online student } \\
\text { services }\end{array}$ & 69.95 & 14.39 & 6.06 & 8.46 & 1.14 \\
\hline $\begin{array}{l}\text { Lack of student self- } \\
\text { motivation }\end{array}$ & 16.79 & 2.90 & 16.41 & 44.95 & 18.94 \\
\hline $\begin{array}{l}\text { Lack of student time } \\
\text { management skills }\end{array}$ & 54.29 & 12.50 & 25.00 & 7.58 & 0.63 \\
\hline $\begin{array}{l}\text { Lack of face-to-face } \\
\text { interaction }\end{array}$ & 40.40 & 18.69 & 16.67 & 15.78 & 8.46 \\
\hline
\end{tabular}


TABLE IX.

RATING 1 TO 5 - ACCORDING TO THE PERCENTAGE OF USERS USAGE (\%) $\mathrm{N}=792$

\begin{tabular}{|l|l|l|l|l|l|}
\hline Description & $\mathbf{1}$ & $\mathbf{2}$ & $\mathbf{3}$ & $\mathbf{4}$ & $\mathbf{5}$ \\
\hline The course objective where clear & 0.88 & 1.89 & 3.16 & 6.31 & 87.75 \\
\hline $\begin{array}{l}\text { The course procedures and the } \\
\text { assignments support course objectives }\end{array}$ & 3.28 & 3.79 & 10.86 & 25.25 & 56.82 \\
\hline $\begin{array}{l}\text { The amount of reading you were asked } \\
\text { to do was appropriate }\end{array}$ & 4.04 & 9.85 & 17.93 & 20.33 & 47.85 \\
\hline $\begin{array}{l}\text { The amount of writing or other class } \\
\text { work you were asked to do was enough }\end{array}$ & 21.84 & 45.83 & 11.36 & 12.37 & 8.59 \\
\hline $\begin{array}{l}\text { Overall, in online courses, how } \\
\text { satisfied are you with }\end{array}$ & 0.00 & 8.21 & 12.37 & 25.13 & 54.29 \\
\hline
\end{tabular}

TABLE $X$.

RATING 1 TO 5 - ACCORDING TO THE PERCENTAGE OF USERS USAGE (\%) $\mathrm{N}=792$

\begin{tabular}{|l|c|c|c|c|c|}
\hline & $\mathbf{1}$ & $\mathbf{2}$ & $\mathbf{3}$ & $\mathbf{4}$ & $\mathbf{5}$ \\
\hline $\begin{array}{l}\text { Online courses require me to be more } \\
\text { self-motivated than traditional courses }\end{array}$ & 6.57 & 10.73 & 27.15 & 23.86 & 31.69 \\
\hline $\begin{array}{l}\text { Compared to traditional courses, I feel } \\
\text { more involved in the online cours- } \\
\text { es/programs }\end{array}$ & 12.37 & 8.59 & 23.99 & 9.22 & 45.83 \\
\hline $\begin{array}{l}\text { Compared to traditional courses, I spend } \\
\text { more time in my online courses. }\end{array}$ & 9.60 & 14.14 & 26.64 & 29.29 & 20.33 \\
\hline $\begin{array}{l}\text { I believe that I learn more through online } \\
\text { courses than through traditional courses. }\end{array}$ & 4.17 & 15.66 & 22.60 & 32.32 & 25.25 \\
\hline $\begin{array}{l}\text { The technical challenges of online } \\
\text { courses / programs are not a problem for } \\
\text { me. }\end{array}$ & 1.52 & 6.19 & 14.14 & 30.56 & 47.60 \\
\hline I prefer online courses & 0.25 & 1.64 & 36.62 & 16.54 & 44.95 \\
\hline $\begin{array}{l}\text { I would benefit if there were more online } \\
\text { courses }\end{array}$ & 4.04 & 30.93 & 33.71 & 15.28 & 16.04 \\
\hline The overall attainment of knowledge & 2.15 & 18.31 & 7.58 & 15.15 & 56.82 \\
\hline $\begin{array}{l}\text { Your ability to interact with the instruc- } \\
\text { tor }\end{array}$ & 27.27 & 5.05 & 6.31 & 14.52 & 46.84 \\
\hline
\end{tabular}

\section{General Information of Online Distance Education}

The survey in table $\mathrm{X}$ tells that online education is much better than the traditional courses because it reduces the human work and also the knowledge attained here is very high comparing to the traditional method. Moreover we can gain knowledge from different sources. Apart from classroom teaching, here we are having some visual teaching also. Students also get involved here. The survey contains the information in all general and deep categories. Here the students preferring the online courses and its usage by them are very high. The students themselves solve the technical challenges faced by them. So that they can develop their technical skills also. We can easily interact with the instructors her.

\section{CONCLUSION}

E-learning's growth, by which education is delivered and supported through computer networks such as Internet, has posed new challenges for library services. The above survey explains the problems and barriers faced in online and distance education. The survey is taken with the help of total number of members (i.e. $n=792$ ). This total is then divided into five ranges (ranges 1 to 5). Based on the point of view and desire of students and faculty, the class is filled. Through the information super highway, elearners and traditional learners have access to a universe of digital information. Internet enables exchange of information without regard to geographical boundaries. Lifelong learning has become a necessity. Given that technology skills are increasingly important to finding employment, lack of access to technology reinforces negative outcomes in the labour market for those with limited education. In the final analysis, no one should be left behind as our nation advances into the 21 st Century, where computers and Internet becomes the key to be a successful member of society. Internet has given several dimensions to equip the quality.

Finally, the findings and nature of this study contain implications for distance education to administrators, teachers, and researchers in MOOCs. By comparing all the resources, we come to know that we are still facing some problem in distance education and also have some problems in attaining the full knowledge and usage about the online education. Also this survey confirms that we are having more or less equal weightage. At a broad management level, this study has given an effective policy to make a balanced investment in distance education and MOOCs programs and provide resources needed for effectively implement the use, integration and diffusion in distance learning rather than paying lip service.

\section{REFERENCES}

[1] J. Block, "Distance Education and the Digital Divide An Academic Perspective," Online J. Distance Learn. Adm., vol. 13, pp. 1-5, 2010.

[2] C. Bouras, A. Philopoulos, and T. Tsiatsos, "e-Learning through distributed virtual environments," J. Netw. Comput. Appl., vol. 24, no. 3, pp. 175-199, 2001. http://dx.doi.org/10.1006/ jnca.2001.0131

[3] B. M. Slator, C. Hill, and D. Del Val, Teaching computer science with virtual worlds, vol. 47, no. 2. 2004, pp. 269-275.

[4] S. C. Trent, B. L. Driver, M. H. Wood, P. S. Parrott, T. F. Martin, and W. G. Smith, "Creating and sustaining a special education/general education partnership: A story of change and uncertainty," Teaching and Teacher Education, vol. 19, no. 2. pp. 203219, 2003. http://dx.doi.org/10.1016/S0742-051X(02)00104-X

[5] C. Z. C. Zhang and F. W. F. Wang, "Student-centered college classroom teaching mode based on network teaching platform," Adv. Manag. Sci. (ICAMS), 2010 IEEE Int. Conf., vol. 2, 2010.

[6] N. P. Ololube, A. E. Ubogu, and D. E. Egbezor, "ICT and Distance Education Programs in a Sub-Saharan African Country: A Theoretical Perspective," J. Inf. Technol. Impact, vol. 7, no. 3, pp. 181-194, 2007.

[7] K. N. Badhusha, Dr. M.Nagarajan, Dr.R.Natarajan, and Dr. S.Thanuskodi, "Recent Trents In Electronic Resources Management Systems (ERM)," Int. J. Prof. Dev., vol. 1, no. 1, pp. 1-98, 2012.

[8] Som Naidu, "Commonwealth of Learning - E-Learning: A Guidebook of Principles, Procedures and Practices," Commonwealth Educational Media Centre for Asia (CEMCA), 2013. [Online]. Available: http://www.col.org/resources/publications/Pages/detail. aspx?PID $=247$.

[9] D. Franklin, J. Budzik, and K. Hammond, "Plan-based Interfaces: Keeping Track of User Tasks and Acting to Cooperate," in Proceedings of the 7th international conference on Intelligent user interfaces - IUI '02, 2002, p. 79.

[10] Yuanchun Shi, Weikai Xie, Guangyou Xu, Runting Shi, Enyi Chen, Yanhua Mao, and Fang Liu, "The smart classroom: merging technologies for seamless tele-education," IEEE Pervasive Comput., vol. 2, no. 2, pp. 47-55, Apr. 2003. http://dx.doi.org/10.1109/MPRV.2003.1203753 
PAPER

EduCATIONAL PARAdigm SHIFT: ARE We REAdy to AdOPT MOOC?

[11] Margaret Rouse and Ivy Wigmore, "Massive Open Online Course (MOOC)," 2013. [Online]. Available: http://whatis.techtarget.com/definition/massively-open-onlinecourse-MOOC

[12] D. Belki and C. Porter, "Job Market Embraces Massive Online Courses," 2013. [Online]. Available: http://online.wsj.com/news/ articles/SB10001424127887324807704579087840126695698

[13] W.N. Bender, "Advantages and Disadvantages of Various Curricular-Content Approaches in Resource Classrooms," 2010. [Online]. Available: http://www.education.com/reference/ article/approaches-resource-classroom

[14] L. Pappano, "The Year of the MOOC - Massive Open Online Courses Are Multiplying at a Rapid Pace," 2012. [Online]. Available:

http://www.nytimes.com/2012/11/04/education/edlife/massiveopen-online-courses-are-multiplying-at-a-rapid-pace.html?_r $=0$

[15] "course-builder - Course Builder - Google Project Hosting," 2012. [Online]. Available: https://code.google.com/p/course-builder/

[16] "NIIT - Learning for careers in Banking, Financial Services, Insurance, IT, Computers, Software, Hardware, Employability Training, School Solutions, College Solutions, Corporate Training, Executive Management." [Online]. Available: http://www.niit.com/pages/defaultindia.aspx

[17] “Consortium for Educational Communication ." [Online]. Available: http://cec.nic.in/edusat/Pages/default.aspx

[18] Aaron Smith, "Smartphone Adoption and Usage," 2011. [Online]. Available: http://www.pewinternet.org/2011/07/11/smartphoneadoption-and-usage/

[19] D. Chaffey, "Mobile usage statistics 2010-2015 - Smart Insights Digital Marketing Advice," 2011. [Online]. Available: http://www.smartinsights.com/mobile-marketing/mobilemarketing-analytics/mobile-usage-statistics-2010-2015/.

[20] "Massive open online course." Wikipedia:The Free Encyclopedia. Wikimedia Foundation, Inc., date last updated (11 May 2013). Available: http://en.wikipedia.org/ wiki/Massive open online course

[21] "ACS providing Smart Card Technology Training to the Chinese University of Hong Kong".2008. [Online]. Available: http: //www.prlog.org/10110599-acs-providing-smart-cardtechnologytraining-to-the-chinese-university-of-hong-kong.html.[Accessed; 13 January, 2010].

[22] "Indira Gandhi National Open University" Wikipedia:The Free Encyclopedia. Wikimedia Foundation, Inc., date last updated (8 May 2013). Available: http://en.wikipedia.org/wiki/ Indira Gandhi National Open University

[23] Z. Khan, "Schools bet big on virtual classrooms," 2013. [Online]. Available: http://www.livemint.com/Politics/1P3kQo6cvnIGytjQ HsWbWP/Schools-bet-big-on-virtual-classrooms.html.

[24] Manish Gupta, "Indian e-Learning Industry Size - 2013," 2013. [Online]. Available: http://www.gc-solutions.net/blog/indian-elearning-industry-size-2013/.

\section{AUTHOR}

Jayakumar $\mathbf{S}$ is with the School of Information Technology and Engineering, VIT University, Vellore 632014, India (e-mail: jayakumars@vit.ac.in).

Submitted 08 April 2014. Published as resubmitted by the author 14 June 2014. 